\title{
Task 1.13 - Data Collection and Database Development for Clean Coal Technology By-Product Characteristics and Management Practices
}

\author{
Semi-Annual Report \\ July 1 - December 31, 1996
}

By

Debra F. Pflughoeft-Hassett
RECEIVED

AUG 131997

OSTI

Work Performed Under Contract No.: DE-FC21-93MC30097

For

U.S. Department of Energy

Office of Fossil Energy

Morgantown Energy Technology Center

P.O. Box 880

Morgantown, West Virginia 26507-0880

By

Energy and Environmental Research Center

University of North Dakota

P. O. Box 9018

Grand Forks, North Dakota 58202-9018

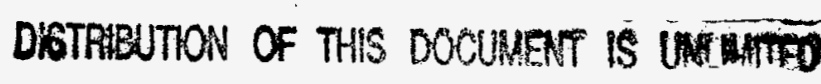
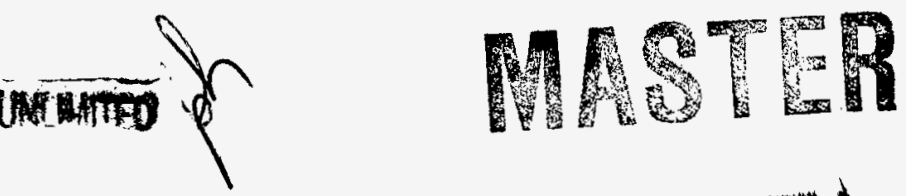


\section{Disclaimer}

This report was prepared as an account of work sponsored by an agency of the United States Government. Neither the United States Government nor any agency thereof, nor any of their employees, makes any warranty, express or implied, or assumes any legal liability or responsibility for the accuracy, completeness, or usefulness of any information, apparatus, product, or process disclosed, or represents that its use would not infringe privately owned rights. Reference herein to any specific commercial product, process, or service by trade name, trademark, manufacturer, or otherwise does not necessarily constitute or imply its endorsement, recommendation, or favoring by the United States Government or any agency thereof. The views and opinions of authors expressed herein do not necessarily state or reflect those of the United States Government or any agency thereof. 


\section{TABLE OF CONTENTS}

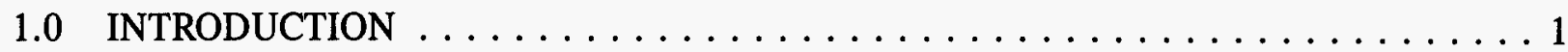

2.0 GOALS AND OBJECTIVES $\ldots \ldots \ldots \ldots \ldots \ldots \ldots \ldots \ldots \ldots \ldots \ldots$

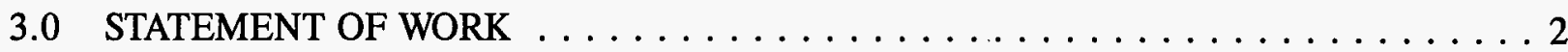

3.1 Subtask 1 - Collect Data on PFBC and Gasification Systems $\ldots \ldots \ldots \ldots \ldots 2$

3.2 Subtask 2 - Assemble CCT By-Product Management Information . . . . . . . . . 2

3.3 Subtask 3 - Finalize EERC Report of Barriers to CCB Utilization . . . . . . . . 2

3.4 Subtask 4 - Develop a CCT By-Product Workshop $\ldots \ldots \ldots \ldots \ldots \ldots$

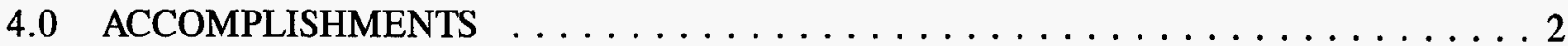




\section{TASK 1.13 - DATA COLLECTION AND DATABASE DEVELOPMENT FOR CLEAN COAL TECHNOLOGY BY-PRODUCT CHARACTERISTICS AND MANAGEMENT PRACTICES}

\subsection{INTRODUCTION}

The U.S. Department of Energy Federal Energy Technology Center's (DOE FETC) efforts in the areas of fossil fuels and clean coal technology have included involvement with both conventional and advanced process coal conversion by-products. In 1993, DOE submitted a Report to Congress on "Barriers to the Increased Utilization of Coal Combustion/Desulfurization Byproducts by Governmental and Commercial Sectors," which provided an outline of activities to remove the barriers identified in the report. DOE charged itself with participation in this process, and the work proposed in this document facilitates DOE's response to its own recommendations for action. The work reflects DOE's commitment to the coal combustion by-product (CCB) industry, to the advancement of clean coal technology (CCT), and to cooperation with other government agencies.

Information from DOE projects and commercial endeavors in fluidized-bed combustion (FBC) and coal gasification is the focus of this task by the Energy \& Environmental Research Center (EERC). The primary goal is to provide an easily accessible compilation of characterization information on the by-products from these processes to government agencies and industry to facilitate sound regulatory and management decisions. Additional written documentation will facilitate the preparation of an updated final version of background information collected for DOE in preparation of the Report to Congress on barriers to $\mathrm{CCB}$ utilization.

The information assembled will be valuable to the Environmental Protection Agency (EPA) in its upcoming decision on the waste status of FBC by-products and must be submitted to EPA in April 1997. This effort facilitates interaction between DOE and industry regarding input to EPA. DOE FETC's efforts to provide this type of information to EPA is consistent with the recommendation in the DOE Report to Congress on ash barriers that a determination placing CCT by-products under Resource Conservation and Recovery Act (RCRA) Subtitle D for solid wastes is needed if these materials are to be utilized. Since several DOE projects have already investigated utilization of these materials, it is an opportunity to give this information the emphasis it deserves.

\subsection{GOALS AND OBJECTIVES}

The primary goal of this task is to provide an easily accessible compilation of characterization information on CCT by-products to government agencies and industry to facilitate sound regulatory and management decisions. Supporting objectives are 1) to fully utilize information from previous DOE projects, 2) to coordinate with industry and other research groups, 3) to focus on by-products from pressurized fluidized-bed combustion (PFBC) and gasification, and 4) to provide information relevant to the EPA evaluation criteria for the Phase II Bevill decision. 


\subsection{STATEMENT OF WORK}

\subsection{Subtask 1 - Collect Data on PFBC and Gasification Systems}

Through literature, industrial and government contacts, and the research community, additional by-product and process data on PFBC systems and gasification systems will be collected and added to the database. Projects supported by DOE are expected to provide significant data for this subtask. It is anticipated that additional contacts, sources, and information will need to be developed through the performance of a literature search, through trade associations, and through personal contacts at utility and industrial plants with these systems in place.

\subsection{Subtask 2 - Assemble CCT Byproduct Management Information}

CCT by-products are relatively new to the CCB utilization industry, so the information collected in Subtask 1 may not include well-developed by-product management information. A specific effort will be made to collect and include management options for PFBC and gasification by-products. Using all contacts and sources developed in the previous subtasks, these options will be identified with the intent to collect specific information on by-product utilization examples, demonstrations, and commercial applications.

\subsection{Subtask 3 - Finalize EERC Report on Barriers to CCB Utilization}

The Energy \& Environmental Research Center (EERC) assembled comprehensive information on CCB production, characteristics, and management options at the request of FETC prior to the submittal of DOE's Report to Congress on Barriers to the Increased Utilization of Coal Combustion/Desulfurization By-Products by Governmental and Commercial Sectors. The draft EERC report focuses on utilization of $\mathrm{CCBs}$ and will have broad applicability for regulatory agencies and CCB users. This report requires revision prior to its being published by FETC, and these revisions will be accomplished according to review comments previously received from FETC. Since this report was originally prepared in 1993, it is also proposed to add an update to the report. This addition to the report will summarize 1) current production and management statistics, 2) regulatory and legislative activities involving CCBs, 3) impacts of technology changes, and 4) new utilization options and standards and specifications.

\subsection{Subtask 4 - Develop a CCT By-Product Workshop}

Following the collection and submittal of the information on CCT by-products, the EERC will work with DOE and industry to develop a workshop designed to inform regulatory agencies and potential users about the properties and management options for CCT by-products.

\subsection{ACCOMPLISHMENTS}

This subtask has been under way since late October 1996. Since that time, the project staff has contacted several industry groups to ascertain the exact information needed to facilitate efforts already under way and to avoid any duplication of effort. The Council of Industrial Boiler Owners (CIBO) was contacted and assisted in refinement of the work plan. CIBO is collecting similar 
information on commercial FBC systems and has agreed to include the information developed in this effort in its database. The EERC will share any information appropriate to CIBO's effort in order to facilitate the effort relative to commercial FBC systems.

General documents on PFBC and gasification were obtained, and a review of these documents was begun. Several phases of a literature search were completed. These searches included searches of the University of North Dakota and EERC library resources; EERC publications and documents, including many prepared for DOE; and the Internet of DOE and EPA sources. These literature searches are currently under review, and specific documents will be obtained as deemed appropriate. A final literature search option will consist primarily of the computer literature search of the National Technical Information Service (NTIS) database. Because of the long time period frequently involved for obtaining documents from NTIS, the DOE FETC Technical Contact may be requested to facilitate the receipt of some documents. Information from uncompleted projects performed at the EERC has been reviewed, and the appropriate DOE person will be contacted to get this information released. At this time, the information is not being limited to full-scale CCT facilities because of the limited number of them in operation, so it expected that laboratory- and pilot-scale information will be included in the report to EPA.

Two utilities have volunteered to provide information on CCT by-product production and management. An information request document was prepared to facilitate their participation. The information document is attached. Continued industry contacts are planned for all full-scale PFBC and gasification facilities. 


\section{ATTACHMENT}

CLEAN COAL TECHNOLOGY BY-PRODUCT CHARACTERISTICS AND MANGEMENT PRACTICES INFORMATION REQUIREMENTS 


\section{CLEAN COAL TECHNOLOGY BY-PRODUCT CHARACTERISTICS AND MANGEMENT PRACTICES INFORMATION REQUIREMENTS}

The U.S. Department of Energy (DOE) has expressed a commitment to working with industry and other government agencies to reduce barriers to utilization of by-products of coal combustion and advanced coal technologies. As DOE recommended in its 1994 Report to Congress, information on by-products from advanced coal technologies needs to be provided to the U.S. Environmental Protection Agency (EPA) so a determination can be made on their status under the Resource Conservation and Recovery Act (RCRA). The Energy \& Environmental Research Center (EERC) is the subcontractor to DOE in an effort to collect information on byproducts from pressurized fluidized-bed combustion and gasification. The EERC seeks information on these by-products to address EPA's Bevill Amendment Waste Evaluation Criteria, which will be used in its regulatory determination. The criteria are as follows:

- Source and volumes generated per year

- Current disposal and utilization practices for the waste

- Potential danger to human health and environment from disposal and use

- Documented cases of the danger of surface runoff or leachate

- Alternatives to current disposal methods

- Costs of alternatives

- Current and potential uses for the waste

The information listed below is requested from your company for inclusion in a database of information on advanced coal technologies that will be submitted to EPA for evaluation.

\section{INFORMATION NEEDED FOR CLEAN COAL TECHNOLOGY BY-PRODUCTS}

- A description of the advanced coal technology being utilized and a process flowchart, including fuel and additive introduction, by-product discharge locations, process recycling functions, gas cleanup systems, entrained particulate removal, and materials recovery.

- A list of the design fuel(s), including start-up, auxiliary, and supplemental fuels and additives for the process and the quantities. Please include typical ranges of characteristics for the fuels and additives (i.e., for coal include proximate-ultimate analysis results and ash fusion temperatures).

- A list of the high-volume by-products generated in the process, quantities produced, and a range of characteristics for each by-product. Please include the following information if possible:

- Description of the appearance of the by-product and/or color photograph of the bulk material.

- Physical properties, including appearance, specific gravity, bulk density, particle-size distribution, moisture content, and maximum dry density. 
- Bulk chemical composition, including major inorganic constituents (silicon, aluminum, iron, calcium, magnesium, sodium, potassium, and sulfur); trace constituents, including metals (at minimum arsenic, barium, cadmium, chromium, lead, mercury, selenium, and silver); dioxins and furans; volatile organics; semivolatile organics; pesticides; polychlorinated biphenyls (PCBs); radionuclides; carbon content; and $\mathrm{pH}$.

- Leachate chemistry from toxicity characteristic leaching procedure (TCLP), synthetic groundwater leaching procedure (SGLP), or American Society for Testing and Materials (ASTM) D34 leaching procedures for metals, dioxins and furans, volatile organics, semivolatile organics, pesticides, PCBs, and radionuclides unless these are not present in the bulk chemical analyses.

- Mineralogical composition, listing minerals present and approximation of crystalline and amorphous content.

- A list of the low-volume by-products/wastes generated in the process, quantities produced, and a range of characteristics for each by-product. These by-products/wastes will be included in EPA's determination if they are comanaged with high-volume by-products. These low-volume by-products/waste may include boiler chemical cleaning wastes, demineralizer regenerant/rinses, coal/storage pile runoff, general site runoff, pyrites, laboratory wastes, water treatment wastes, domestic/municipal wastes, and miscellaneous plant wastes.

- Current management practices for both the high- and low-volume by-products, including disposal types and any beneficial uses. Include the environmental risks associated with disposal and use options and any environmental protection practices for management options. Also please outline any regulatory (federal, state, or local) requirements for mangement options, such as analyses, liners, leachate collection, or dust control.

- List any alternatives to current by-product management practices and the potential economic impacts of these alternatives.

If you have any questions regarding the information requested, please feel free to contact Debra Pflughoeft-Hassett by telephone at (701) 777-5261, by fax at (701) 777-5181, or e-mail at dphassett@eerc.und.nodak.edu. Thank you. 
J:IBÁY4T104

FORM EIA-459E

(10/88)

1. Program/Project Identification No.

DE-FC21-93MC30097

4. Name and Address
U.S. DEPARTMENT OF ENERGY

FEDERAL ASSISTANCE MANAGEMENT SUMMARY REPORT

FORM APPROVED

OMB NO. 19000127

Page 1 of 3

2. Program/Project Title

TASK 1.0 WASTE MANAGEMENT

Energy \& Environmental Research Center

University of North Dakota

PO Box 9018, Grand Forks, ND 58202-9018 $\quad$ (701) 777-5000
3. Reporting Period

10-1-96 through 12-31-96

5. Program Start Date

$01-12-93$

6. Complation Date $12-31-97$

\begin{tabular}{|c|c|}
\hline $\begin{array}{c}\text { 7. FY } \\
96 / 97\end{array}$ & $\begin{array}{c}\text { 8. Months or Quarters } \\
\text { Quarters }\end{array}$ \\
\hline $\begin{array}{c}\text { 9. Cost } \\
\text { Status }\end{array}$ & a. Dollars Expressed In \\
Thousands
\end{tabular}

10. Cost Chart

\begin{tabular}{|c|c|c|c|c|c|c|c|}
\hline \multirow{2}{*}{$\begin{array}{l}\text { Fund } \\
\text { Source }\end{array}$} & & \multicolumn{4}{|c|}{ Quarter } & \multirow{2}{*}{$\begin{array}{c}\text { Cum. } \\
\text { to } \\
\text { Date }\end{array}$} & \multirow[b]{2}{*}{$\begin{array}{l}\text { Tot. } \\
\text { Plan }\end{array}$} \\
\hline & & ist & 2nd & \multirow{2}{*}{$\frac{3 \mathrm{rd}}{34}$} & \multirow{2}{*}{$\frac{4 \text { th }}{64}$} & & \\
\hline DOE & $\mathbf{P}$ & 38 & 34 & & & 170 & 235 \\
\hline & A & 0 & 61 & 57 & 26 & 144 & \\
\hline & $\mathbf{P}$ & & & & & & \\
\hline & A & & & & & & \\
\hline & $\mathbf{P}$ & & & & & & \\
\hline & A & & & & & & \\
\hline & $P$ & & & & & & \\
\hline & A & & & & & & \\
\hline Tot & & 38 & 34 & 34 & 64 & 170 & 235 \\
\hline Tot: & & 0 & 61 & 57 & 26 & 144 & \\
\hline Varia & & 38 & (27) & (23) & 38 & 26 & \\
\hline
\end{tabular}

Total Planned Costs for Program/Project

$\$ 235$
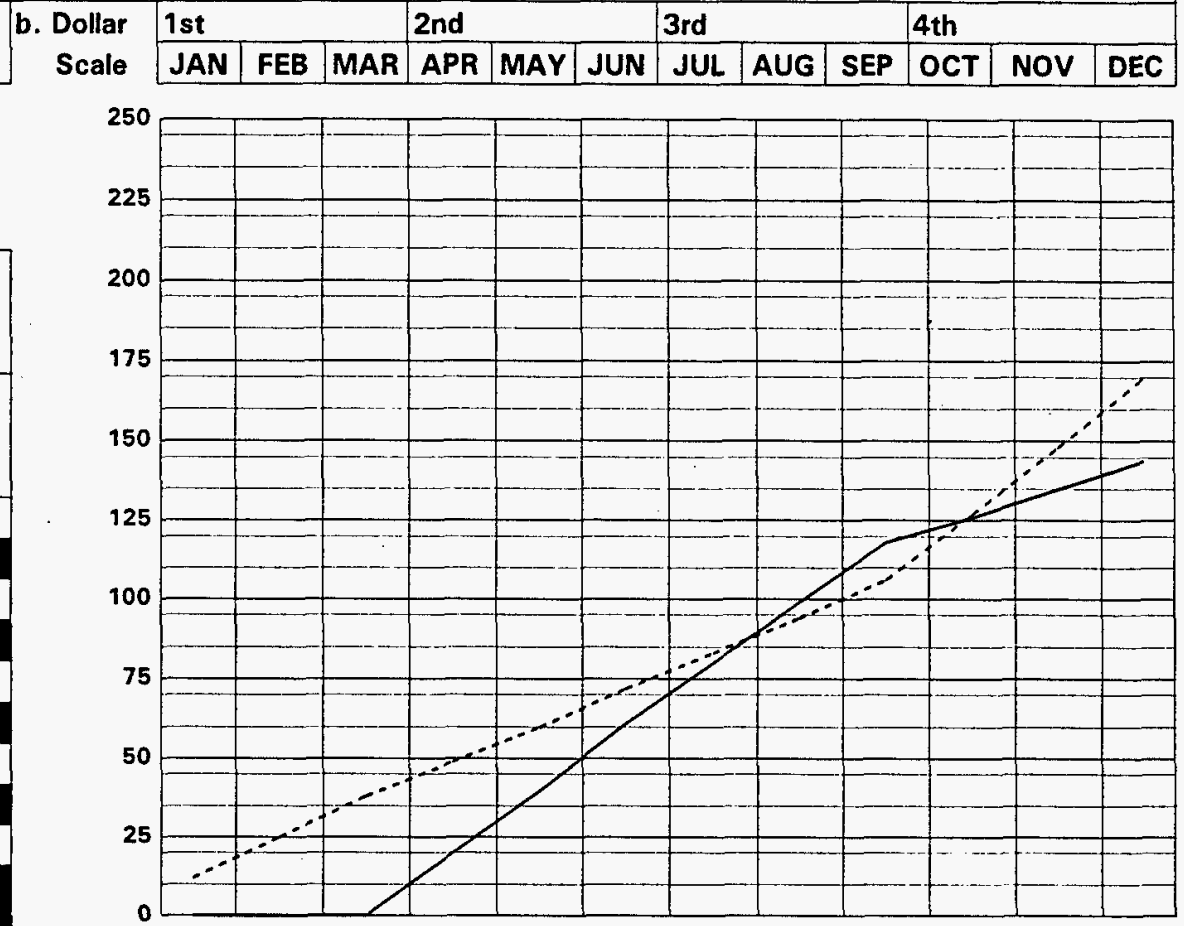

c. Cumulative Accrued Costs

\begin{tabular}{|l|r|r|l|l|r|r|r|r|r|r|r|}
\hline Planned & & 38 & & & 72 & & & 106 & & & 170 \\
\hline Actual & & & 0 & & & 61 & & & 118 & & \\
\hline Variance & & 38 & & & 11 & & & -12 & & & 26 \\
\hline
\end{tabular}

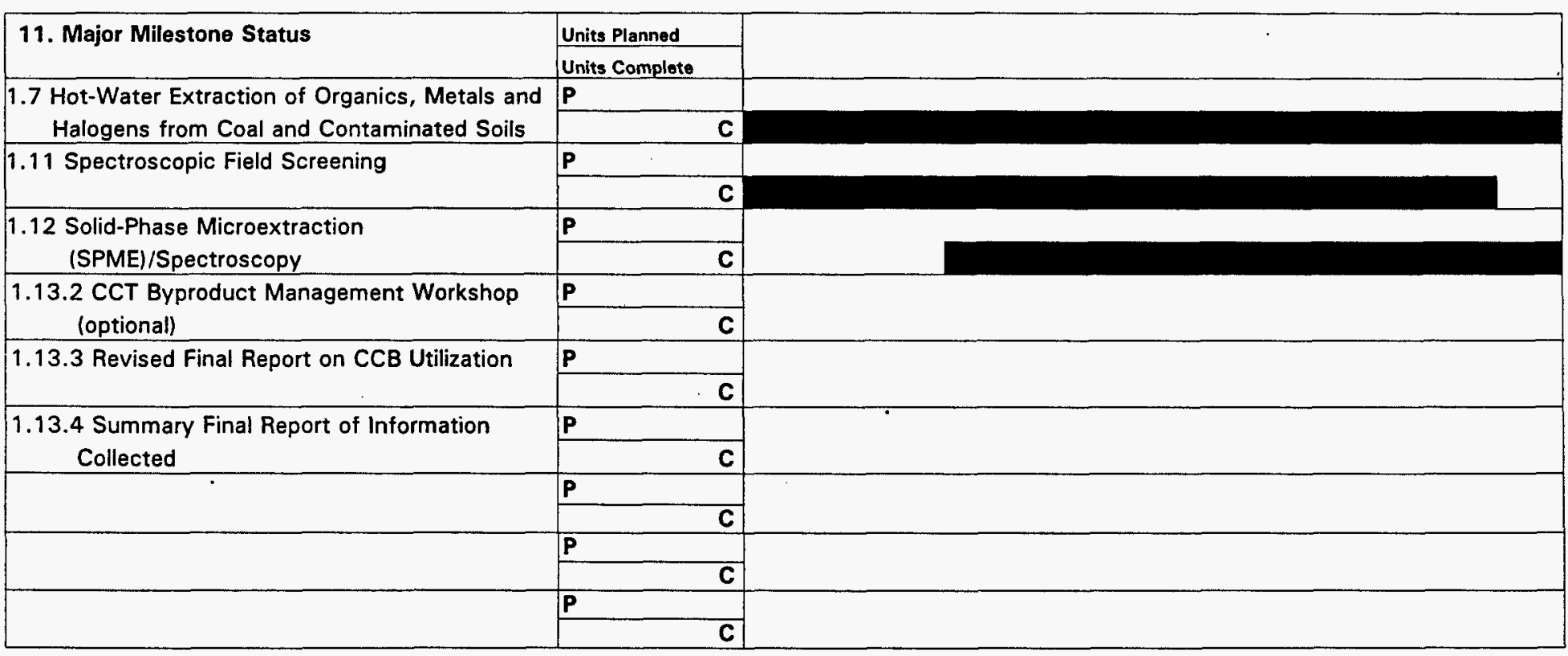

\section{Remarks}


JiLAYT4TIOA

FORM EIA-459E

(10/88)

1. Program/Project Identification No.

DE-FC21-93MC30097

4. Name and Address
U.S. DEPARTMENT OF ENERGY

FEDERAL ASSISTANCE MANAGEMENT SUMMARY REPORT

. Program/Project Titie

TASK 1.0 WASTE MANAGEMENT

Energy \& Environmental Research Center

University of North Dakota

PO Box 9018, Grand Forks, ND 58202-9018 (701) 777-5000
FORM APPROVED

OMB NO. 19000127

Page 2 of 3

3. Reporting Period

10-1-96 through $12-31.96$

5. Program Start Date

01-12-93

6. Completion Date

12-31-97
7. FY
8. Months or Quarters
97
9. Cost
Status
a. Dollars Expressed in
Thousands

10. Cost Chart

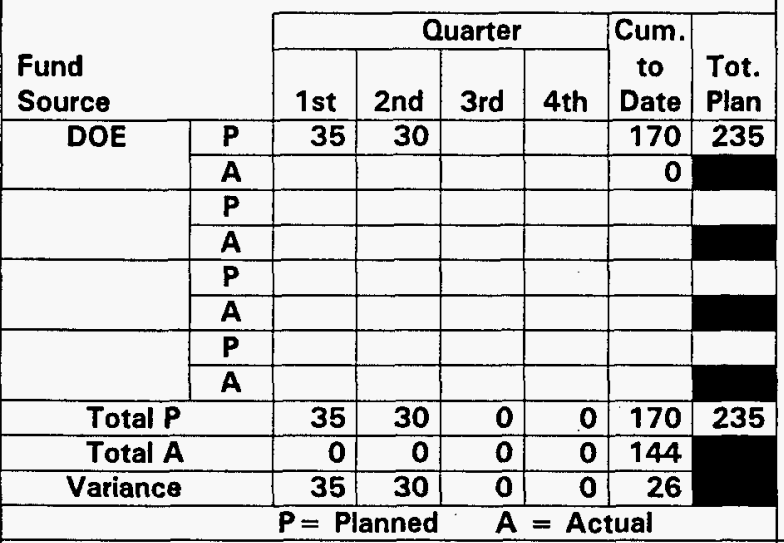

Total Planned Costs for Program/Project $\$ 235$

\section{b. Dollar 1st}

\begin{tabular}{l|l|l|l|l|l|l|l|l|l|l|l|l|} 
Scale & JAN & FEB & MAR & APR & MAY & JUN & JUL & AUG & SEP & OCT & NOV & DEC \\
\cline { 2 - 6 } & &
\end{tabular}

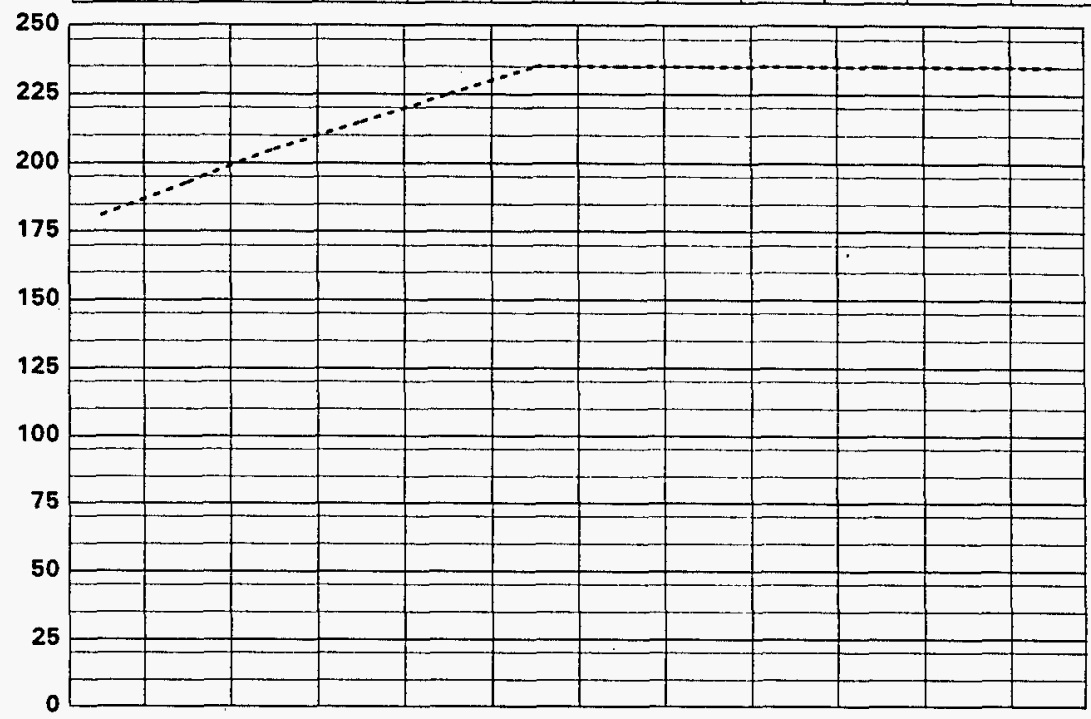

c. Cumulative Accrued Costs

\begin{tabular}{|l|r|r|l|l|r|r|r|r|r|r|r|}
\hline Planned & & 205 & & & 235 & & & 235 & & & 235 \\
\hline Actual & & & 0 & & & 0 & & & 0 & & \\
\hline Variance & & 205 & & & 235 & & & 235 & & & 235 \\
\hline
\end{tabular}

\begin{tabular}{|c|c|c|}
\hline \multirow[t]{2}{*}{ 11. Major Milestone Status } & Units Planned & \\
\hline & Units Complete & \\
\hline \multirow{2}{*}{$\begin{array}{c}\text { 1.7 Hot-Water Extraction of Organics, Metals and } \\
\text { Halogens from Coal and Contaminated Soils }\end{array}$} & $\mathbf{P}$ & \\
\hline & C & \\
\hline \multirow[t]{2}{*}{ 1.11 Spectroscopic Field Screening } & $\mathbf{P}$ & \\
\hline & $\mathbf{C}$ & \\
\hline \multirow{2}{*}{$\begin{array}{l}1.12 \text { Solid-Phase Microextraction } \\
\text { (SPME)/Spectroscopy }\end{array}$} & $\mathbf{P}$ & \\
\hline & C & \\
\hline \multirow{2}{*}{$\begin{array}{l}\text { 1.13.2 CCT Byproduct Management Workshop } \\
\text { (optional) }\end{array}$} & $\mathbf{P}$ & \\
\hline & c & \\
\hline \multirow{2}{*}{$\begin{array}{l}\text { 1.13.3 Revised Final Report on CCB Utilization } \\
\text { (optional) }\end{array}$} & $\mathbf{P}$ & \\
\hline & C & \\
\hline \multirow{8}{*}{$\begin{array}{l}\text { 1.13.4 Summary Final Report of Information } \\
\text { Collected }\end{array}$} & $\mathbf{P}$ & \\
\hline & C & \\
\hline & $\mathbf{P}$ & $\cdot$ \\
\hline & $\mathbf{C}$ & \\
\hline & $\mathbf{P}$ & \\
\hline & C & \\
\hline & $\mathbf{P}$ & \\
\hline & c & \\
\hline
\end{tabular}

\section{Remarks}

13. Signature of Recipient apd Date 政 $2 / 3 / 97$

14. Signature of DOE Reviewing Representative and Date 
FORM EIA-459E $(10 / 80)$
U.S. DEPARTMENT OF ENERGY FEDERAL ASSISTANCE MANAGEMENT SUMMARY REPORT
FORM APPROVED

OMB NO. 19000127

Page 3 of 3

3. Program/Project Identification No. DE-FC21-93MC30097

4. Name and Address

3. Reporting Period 10/1/96 through 12/31/96

5. Program Start Date
2. Program/Project Title TASK 1.0 WASTE MANAGEMENT

Energy \& Environmental Research Center

University of North Dakota

PO Box 9018, Grand Forks, ND 58202-9018 $\quad$ (701) 777-5000
1-12-93

6. Completion Date 12-31-97

Milestone

ID. No.

Subtask 1.7

a

b

Subtask 1.11

a

b

c

Subtask 1.12

a

b

c

Subtask 1.13.2 CCT Byproduct Management Workshop (optional)

Subtask 1.13.3 Revised Final Report on CCB Utilization

Subtask 1.13.4 Summary Final Report of Information Collected
The relative advantages and disadvantages of three to five polymeric and for their ability to concentrate model organic pollutants from water will be reported

Prototype dipstick devices will be constructed with the best of the sorbent films

Analytical characteristics of the sorbent films (e.g., selectivity, sensitivity, ability to perform quantitative determinations) for organic pollutants (e.g., aromatic fuel hydrocarbons and chlorinated solvents) in real water samples will be reported sorbent films for their optical clarity with UV and/or FT-IR spectroscopy
Actual

\begin{tabular}{l|l}
\hline Planned & Actual \\
Completion & Completion
\end{tabular}

Date Date

$6 / 96$

$12 / 96$

$6 / 96$

$8 / 96$

$11 / 96$

$90 \%$

$0 \%$

$8 / 96$

$100 \%$

$10 / 96$

$100 \%$

$12 / 96$

$100 \%$ 
M97002226

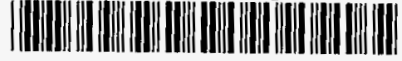

Report Number (14) Dot/MC/30097-- 5579

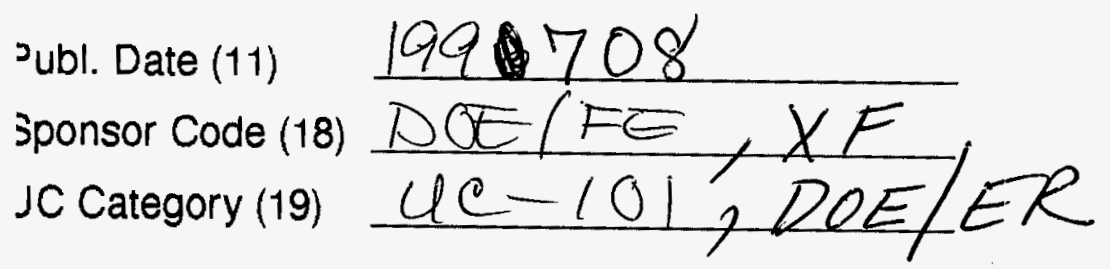




\title{
A software system for the analysis of the "giornate" sequences in frescoes
}

\author{
poster presented at the day conference on \\ "The analysis of pigments and plasters" \\ British Museum, London 22-2-1997
}

organized by the Wall Paintings Section of the United

Kingdom Institute for Conservation

\section{Bertorello^, L. Bordoni^^, A. Colagrossi*, G. Martellotti^, C. Seccaroni**}

${ }^{\wedge}$ C.B.C. - Conservazione Beni Culturali Roma

*IASI-CNR Roma

$\wedge \wedge$ ENEA/STUDI/Doe - C.R. Casaccia Roma

**ENEA/INN/Art-C.R. Casaccia Roma 


\begin{abstract}
This paper reports on a software system for the analysis of the giornate sequences in frescoes, based on mathematical modelling. This model takes into account whole giornate and the relations defined on them by the temporal precedence in their realisation. A sample application is provided on frescoes by Luca Signorelli in the Cappella di San Brizio in the Orvieto Cathedral.
\end{abstract}

[Computer software, computer art, fresco, plasters, wall painting, Signorelli]

\title{
RIASSUNTO
}

Viene presentato lo sviluppo di un sistema software per l'analisi della sequenza di esecuzione delle giornate di un affresco. Tale sistema si basa su una modellizzazione matematica che considera da un lato l'insieme delle giornate e dall'altro la particolare relazione tra di esse, definita dalla precedenza temporale nella realizzazione. Viene inoltre fornita un'applicazione del sistema su affreschi eseguiti da Luca Signorelli nella Cappella di San Brizio nel Duomo di Orvieto. 


\section{PROBLEM DEFINITION}

The technique of the fresco needs the execution of the painting directly on the wet plaster, before the carbonatation on its surface; for this reason the plaster must be drawn up only in the zone to be painted in one day (giornata). The careful examination of the joint between two adjacent giornate allows one to detect the overlapping of the plasters, so it is possible to establish the temporal precedence in the realisation of the interested giornate. The examination of the binary relationships concerning all the couples of adjacent giornate on the whole surface of a fresco permits to focalize the going on of the works during the execution of the painting. In the case of frescoes having a wide extension, the giornate number can be very high, so it is very difficult to consider and to elaborate the whole information concerning the joints.

The software system implemented for the analysis of the giornate in fresco paintings is based on a mathematical modelling that takes into account the whole giornate and the relation defined on them by the temporal precedence in their realisation. The mathematical model that fits this specific situation is the model of the direct acyclic graphs (dag).

\section{CHARACTERISTICS OF THE SYSTEM}

In addiction to the temporal sequence the system allows:

- to point out possible anomalies, due to errors in the detection of the direction of the joints among the giornate, for example by the indication of the presence of loops;

- to simulate and to elaborate the different possible interpretations in the case it is impossible to detect the direction of the joints;

- to improve the readability of the whole giornate sequence by clustering selected subsequences.

The software system processes information concerning the overlapping of the plaster among one giornata and all the other adjacent giornate; it automatically eliminates redundant information by applying the maximal path algorithm; so it is possible to obtain the correct temporal sequence for the execution of the giornate.

The system runs on personal computer under MS-DOS operative system and it does not need any sophisticated configuration. In order to enable the graphic visualisation mode, it is necessary a WINDOWS 3.1 version or greater.

The system makes available to the user a wide number of features, implemented by means of several program modules. The system's features are:

- inserting, updating, deleting and accessing data concerning the plasters overlapping for the whole giornate in the fresco;

- detecting possible loops in the graph corresponding to the inserted data;

- processing the graph corresponding to the inserted data yielding an acyclic graph with no redundant information;

- visualising the resulting graph;

- constructing clustered graphs. 
The data input occurs after a preliminary numbering of all the giornate of the fresco. At this point all that is needed is to enter the couples of numbers corresponding to the adjacent giornate and to the direction of their junction.

The inserted graph elaboration is made by a module that implements the maximal path algorithm. This elaboration must be preceded by the verification of the loops presence in the graph supplied by the user. This test is automatically carried out by the system which, whenever a loop is detected, points out all the nodes interested by the loop.

The result of the execution of the module based on the maximal path algorithm is provided in two distinct modes, depending on the user's choice:

(1) couples of numbers, corresponding to the giornate;

(2) the usual graphical representation: nodes connected by arcs.

Before producing clustered graphs a preliminary selection of the graph nodes to be clustered in only one node must be done.

\section{LOOPS, LACK OF INFORMATION AND CLUSTERING}

A loop occurs when, following the information concerning the joints of two or more giornate, the program comes to a previously examined giornata; this is a collapse situation because the sequence for the ordered giornate assumes a ring structure. The existence of a loop is unacceptable because it is incompatible with the precedence relations inferred by the overlapping of the plasters at the joints. Further, a loop makes the program removing the redundant information non-terminating. In order to avoid such a critical situation, when a loop is detected the program points out this situation and all the giornate interested by the loop. This signal allows the user to visualise the loop on the plotting, so it will possible to verify directly on the fresco surface the overlapping of the interested joints and to change the incorrect information in the input file.

If it is not possible to look over the fresco surface, the loop elimination can be done inverting the direction of one or more joints following opportune considerations. Alternatively, it can be done considering as only one giornata all the giornate that are interested by the loop (in this case the giornate must be adjacent).

The absence of information concerning either the recognition of giornate or the direction of the plaster overlapping in the joints, can substantially modify the final result; the amount of the produced alteration depends on the information lack in the input data.

In the second case, that is when it is impossible to ascertain the precedence between two adjacent giornate, it must be underlined that this circumstance can not be determinant for the reconstruction of the real sequence: in fact the impossibility to establish a precedence relation between two adjacent giornate sometimes can not determine a real loss of information. The system is able to establish if the unregistered information is redundant, i.e. it does not determine any change in the correct ordering, on the other hand it is essential, because its nonregistration causes a different solution by the algorithm.

The reconstruction of only one linear sequence is an extremely rare case; in fact, the increment of the number of the giornate makes the graph very branched.

Especially for frescoes having a wide extension some considerations concerning the organisation of the work allow one to pick up additional information for the general ordering of all the giornate, independently from the study of the joints. For instance it is evident that if it is possible to know the borders due to the level of the scaffold used for the realisation of the 
fresco, like it happens between two adjacent giornate, it is possible establish a precedence relation between all the giornate under the above scaffold level and those under it. This operation allows for clustering the giornate, so that during the execution of the program all those giornate are treated as one only giornata.

\section{A SAMPLE APPLICATION}

This software system has been tested on the frescoes by Beato Angelico and Luca Signorelli in the Cappella di San Brizio in the Orvieto Cathedral; the whole fresco surface consists of more than 900 giornate. In figure 2 is shown the sequence concerning the giornate map for the Hell painted by Luca Signorelli; the same is shown as a graph in figure 3. In figure 4 and in figure 5 the situation concerning the Heaven, in the same Chapel, is shown. In both the maps the supposed levels for the scaffold are shown, they are different for number and tallness in this two scenes; finally in the graphs the giornate concerning local correction are shown with round areas.

The comparison of the situation for these two scenes clearly shows that for the Heaven the works have been processed in a more articulate way. For the Hell, on the contrary, with the exclusion of the branches due to the giornate concerning local corrections, four long linear sequences have been evidenced. Stylistic and technical considerations allow one to make the hypothesis that the Hell was the first scene frescoed by the painter on the walls of the Chapel, so it is interesting to have verified that this scene is different from the other also for the giornate organisation. The less branched structure of the Hell could be due to the absence of assistants in the first phase of the works; this circumstance allows to the painter to directly evaluate the problems due to the planning and the realisation of so large scenes. During the recent restore of the whole frescoes in the Chapel it has been verified in the Hell a greater number of corrections and a secco finishings; these corrections also concern the architectural structure of the scene.

\section{BIBLIOGRAPHY}

M. Bottoni, M. Cordaro, M.C. Gaetani, B. Provinciali: Sviluppo di un sistema sperimentale per l'analisi dinamica delle fasi di esecuzione di affreschi. Finalità e fasi del progetto. $2^{\mathrm{a}}$ Conferenza Internazionale sulle prove non distruttive, metodi microanalitici e indagini ambientali per lo studio e la conservazione delle opere d'arte, Perugia 17-20 aprile 1988, vol. I 13.1-15.

G. Ausiello, A. Marchetti Spaccamela, M. Protasi: Teoria e progetto di algoritmi fondamentali, Franco Angeli, Milano, 1988.

C. Batini, L. Carlucci Aiello, M. Lenzerini, A. Marchetti Spaccamela, A. Miola: Fondamenti di programmazione dei calcolatori elettronici, Franco Angeli, Milano, 1992. 
Fig. 1 - Luca Signorelli: the Hell. Particular with the overlapping of the plasters at the joint among the giornate.

Fig. 2 - Luca Signorelli: the Hell. Map of the giornate with the paths of the execution sequence.

Fig. 3 - Luca Signorelli: the Hell. Sequence of the giornate.

Fig. 4 - Luca Signorelli: the Heaven. Map of the giornate with the paths of the execution sequence.

Fig. 5 - Luca Signorelli: the Heaven. Sequence of the giornate. 


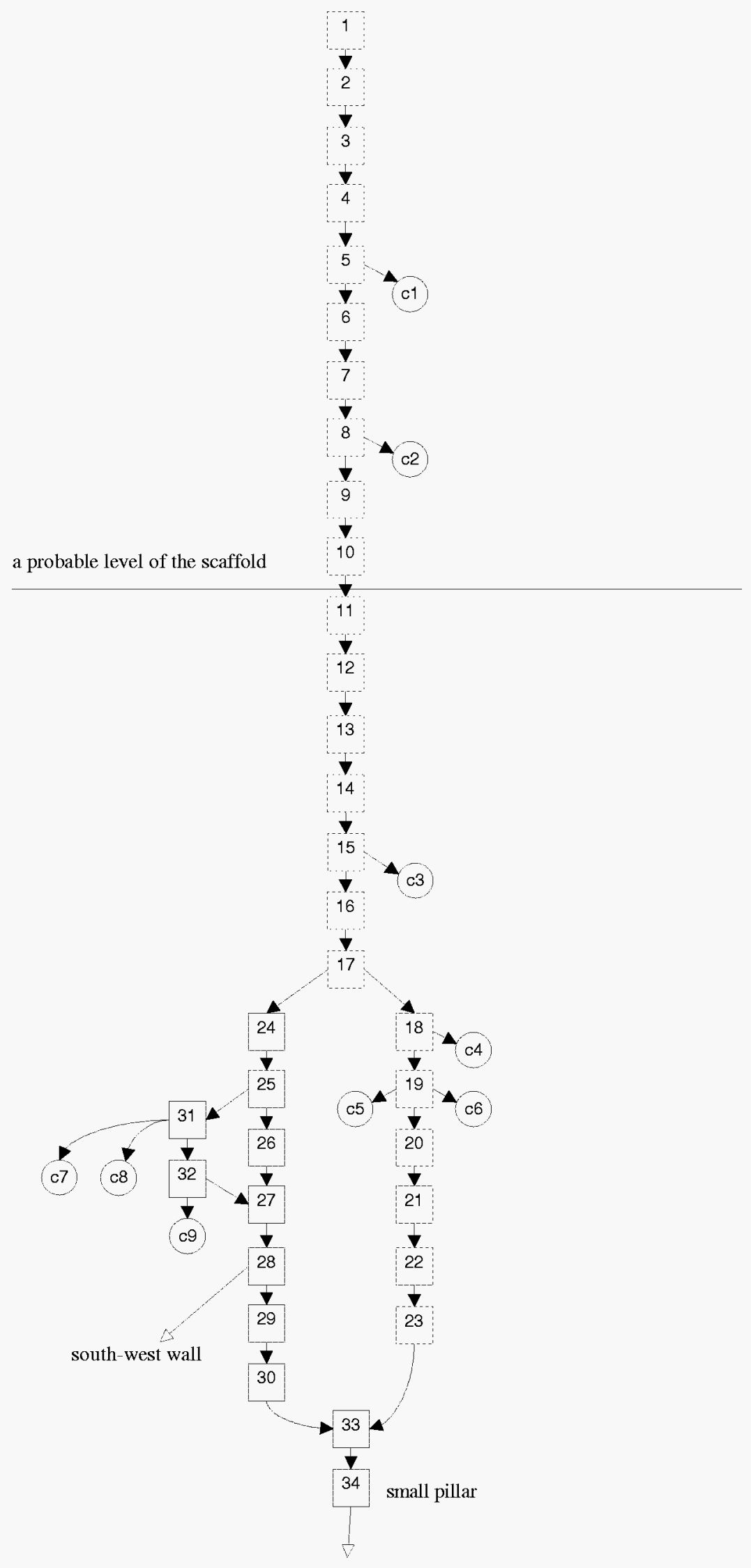

The Resurrection of the body

Figure 3 


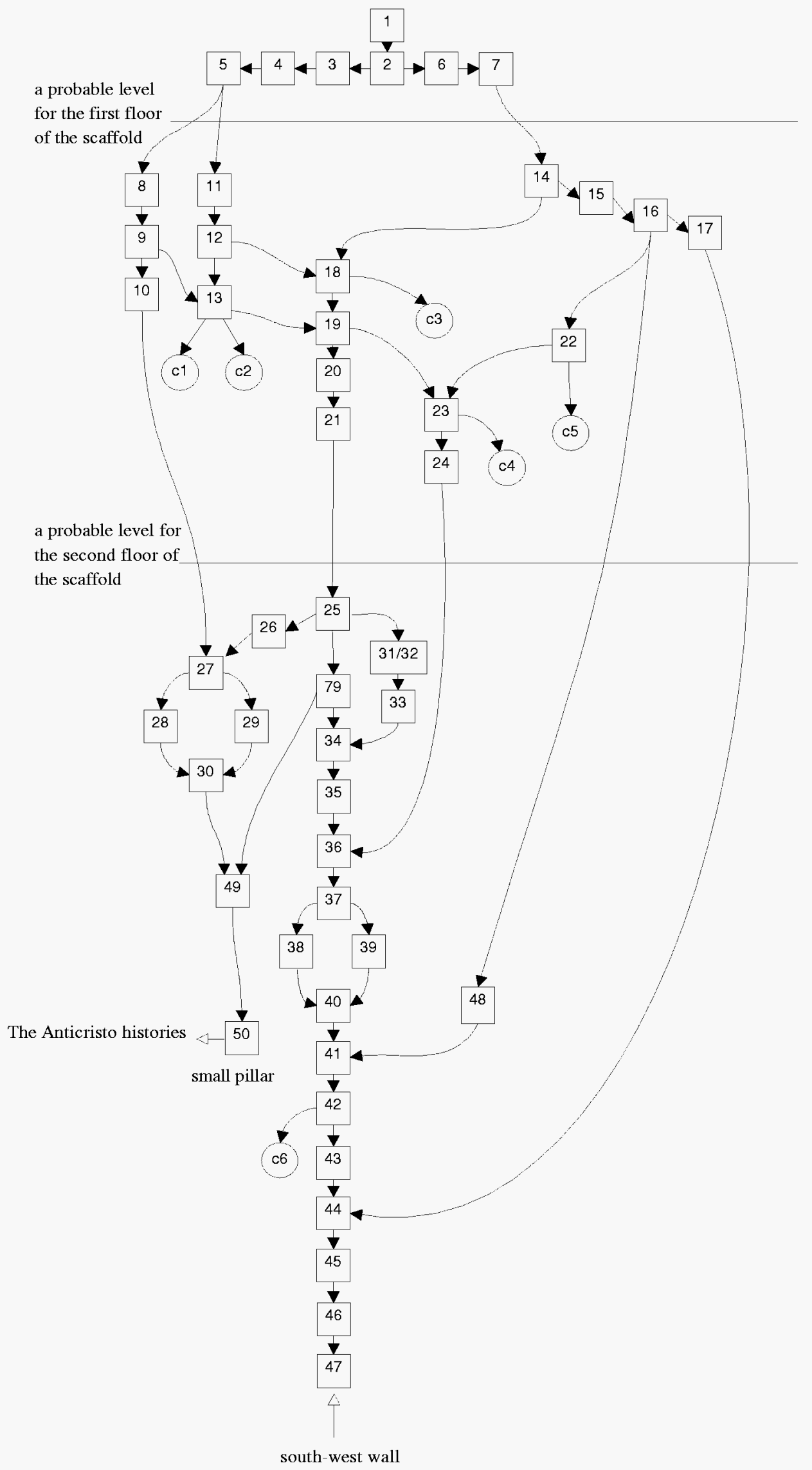

Figure 5 
